\title{
Aluminium toxicity to rainbow trout at low $\mathrm{pH}$
}

\section{Daniel Dietrich and Christian Schlatter}

Institute of Toxicology, Swiss Federal Institute of Technology and University of Zurich, Schwerzenbach.

Switzerland

An acute toxicity study of aluminium at low $\mathrm{pH}$, using one-year-old rainbow trout (Salmo gairdneri R.), was performed in a closed recirculating system at $\mathrm{pH} 5.2,5.4$, and 5.6 with nominal concentrations of $0,100,200$, and $400 \mu \mathrm{g} \mathrm{A1} / 1$. Mortality $(96 \mathrm{~h}$ ) was dependent on the $\mathrm{pH}$ and aluminium concentration. Measurements of aluminium in the plasma of exposed fish, by electrothermal atomic absorption spectrometry (ETAAS), showed a dose-dependent uptake of aluminium, but no correlation of plasma aluminium concentration to the mortality observed. Three major mechanisms of $\mathrm{pH}-\mathrm{Al}$ toxicity seemed to prevail:

i. Relatively low nominal aluminium concentrations ( 100 and $200 \mu \mathrm{g} / \mathrm{l})$ at pH 5.2 as well as $200 \mu \mathrm{g} \mathrm{Al} / 1$ at $\mathrm{pH} 5.4$ led to electrolyte loss possibly due to an interaction of aluminium with enzymes and epithelial tight junctions in the gill of the exposed fish.

ii. Exposing fish to $\mathrm{Al}$ concentrations $\geqslant 100 \mu \mathrm{g} / \mathrm{l}$ and $\mathrm{pH}$ values $\geqslant 5.2$ enhanced cell necrosis, proliferations, and fusions of the secondary lamellae in the gills resulting in the obstruction of the interlamellar space and thus most likely in the impairment of gas exchange. Aluminium fractionation suggested that inorganic monomeric Al was responsible for this tissue damage.

iii. High aluminium concentrations $(\geqslant 200 \mu \mathrm{g} / \mathrm{l})$ at moderately low $\mathrm{pH}(\geqslant 5.4)$ led to clogging of the gills with mucus and thus to an impairment of gas exchange. This mucification was thought to stem from the physical irritation of the gills by accumulating polymeric Al.

Key words: Plasma-Aluminium: Mucification; Cytotoxicity; Ionoregulation; Histopathology; Aluminium

\section{INTRODUCTION}

Acidified waters have been recognized as a problem for freshwater fisheries in Europe and North America. Intensive research resulted in the identification of aluminium (A1) as the major fish toxicant besides low $\mathrm{pH}$. A review of the current literature on aluminium and $\mathrm{pH}$-toxicity to fish (Wood and McDonald, 1987; Witters et al., 1987; Baker, 1982; Muniz and Leivestad, 1980a and b; Schofield and Trojnar, 1980, and Leivestad et al., 1987) reveals that the mechanism of aluminium toxicity is still a matter of controversy, especially in the $\mathrm{pH}$ range 5.0 to 6.0 .

Correspondence and requests for reprints to: D. Dietrich, Institute of Toxicology, Swiss Federal Institute of Technology and University of Zurich, CH-8603, Schwerzenbach, Switzerland. 
Many authors (Baker, 1982; Grahn, 1980; Dickson, 1983; Leivestad et al., 1980; Rosseland, 1980; and Muniz and Leivestad, 1980b) found that fish damaged by exposure to waters supersaturated with respect to $\mathrm{Al}(\mathrm{OH})_{3}$, had gills clogged with mucus and showed symptoms of asphyxiation (reduced blood $\mathrm{O}_{2}$ saturation, elevated blood lactate levels, and increased ventilation rates). This mucification and subsequent asphyxiation was attributed to the physical irritation of the gill epithelia by precipitating polymeric $\mathrm{Al}(\mathrm{OH})_{3}$ onto the gill surface, an aluminium form which prevails even at low total aluminium concentrations at $\mathrm{pH}$ values between 5.0 and 6.0 (Burrows, 1977).

Contrary to the observations above, neither Skogheim et al. (1984), Fivelstad and Leivestad (1984), nor Hutchinson et al. (1987) could detect mucification on the gills of fish exposed under similar conditions in the laboratory as well as in the field. As only two of the numerous reported mucifications came from field experiments (Grahn, 1980, and Dickson, 1983), mucification and subsequent asphyxiation was considered to be an experimental artefact inherent to laboratory testing (Leivestad et al., 1987) and possibly due to the choice of $\mathrm{Al}_{2}\left(\mathrm{SO}_{4}\right)_{3}$ as aluminium source (Rosseland and Skogheim, 1984, Rosseland et al., 1988). Based on this controversy, we thought it important to conduct experiments with $\mathrm{AlCl}_{3}$ as aluminium source with the aim to gain further information on the mechanisms of $\mathrm{pH}-\mathrm{Al}$ toxicity.

In many cases without mucification, an important loss of body electrolytes ( $\mathrm{Na}$ and $\mathrm{Cl}$ ) was observed in fish exposed to aluminium at low $\mathrm{pH}$. The electrolyte loss was thought to stem from the opening of the branchial tight junctions due to an interaction of the epithelia with accumulating aluminium on the gill (Wood and McDonald, 1987). This hypothesis though, is currently disputed by Lacroix and Townsend (1987), who could not find a correlation between aluminium accumulation on the gills and electrolyte loss. Kjartansson (1984) and Staurnes et al. (1984) were able to show that the Na-K-ATPase, responsible for electrolyte uptake, is inhibited by aluminium. Thus either accumulating aluminium on the gills of the fish and/or systemic aluminium must interact with the tight junctions of the gill epithelia and the enzymes therein. While the correlation of gill-aluminium with electrolyte loss is still being disputed, systemic aluminium has never been measured. It cannot be ruled out a priori that systemic aluminium may be responsible for the interactions mentioned above and thus for the toxicity, possibly explaining some of the controversial results obtained so far. A further objective of our investigation was therefore to measure the plasma aluminium concentration (PAC) of aluminium exposed fish and try to relate our findings to mortalities and electrolyte losses.

\section{MATERIALS AND METHODS}

\section{Experimental animals}

All experiments were performed with approximately 1-year-old rainbow trout, Salmo gairdneri Richardson (21-142 g wet weight). The fish were purchased at a com- 
TABLE I

COMPOSITION OF EPA-MEDIUM AS ANALYSED DURING ACCLIMATIZATION AND EXPERIMENTATION (WATER ANALYSIS, 1983)

\begin{tabular}{lllr}
\hline $\mathrm{NH}_{4}-\mathrm{N}$ & $<0.02 \mathrm{mg} / \mathrm{l}$ & $\mathrm{Cl}$ & $1.6 \pm 0.1 \mathrm{mg} / \mathrm{l}$ \\
$\mathrm{NO}_{2}-\mathrm{N}$ & $<0.002 \mathrm{mg} / 1$ & $\mathrm{SO}_{4}$ & $27.3 \pm 1.4 \mathrm{mg} / 1$ \\
$\mathrm{NO}_{3}-\mathrm{N}$ & $<0.1 \mathrm{mg} / \mathrm{l}$ & Ca-Hardness & $14.8 \pm 4.4 \mathrm{mg} / \mathrm{l}$ \\
$\mathrm{PO}_{4}-\mathrm{P}$ & $<0.01 \mathrm{mg} / 1$ & Total-Hardness & $52.5 \pm 2.8 \mathrm{mg} / 1$ \\
$\mathrm{Total}-\mathrm{P}$ & $<0.01 \mathrm{mg} / 1$ & $\mathrm{O}_{2}$ (Winkler) & $9.9 \pm 0.4 \mathrm{mg} / 1$ \\
$\mathrm{DOC}$ & $<0.2 \mathrm{mg} / 1$ & Conductivity & $162 \pm 9 \mu \mathrm{S} / \mathrm{cm}$ \\
\hline
\end{tabular}

mercially run fish hatchery in Andelfingen, Switzerland. All fish were acclimatized to soft water conditions (Table I) for $48 \mathrm{~h}$ prior to the experiments. The water was exchanged every $24 \mathrm{~h}$ in order to reduce any accumulation of excretory products. The fish were not fed during the acclimatization and the experiments.

\section{Experimental unit}

All experiments were done by using a temperature-controlled $\left(10 \pm 1^{\circ} \mathrm{C}\right)$ recirculating system (Fig. 1). The flow rate was $1200 \mathrm{l} / \mathrm{h}$ and the total volume $436 \mathrm{l}$. The water

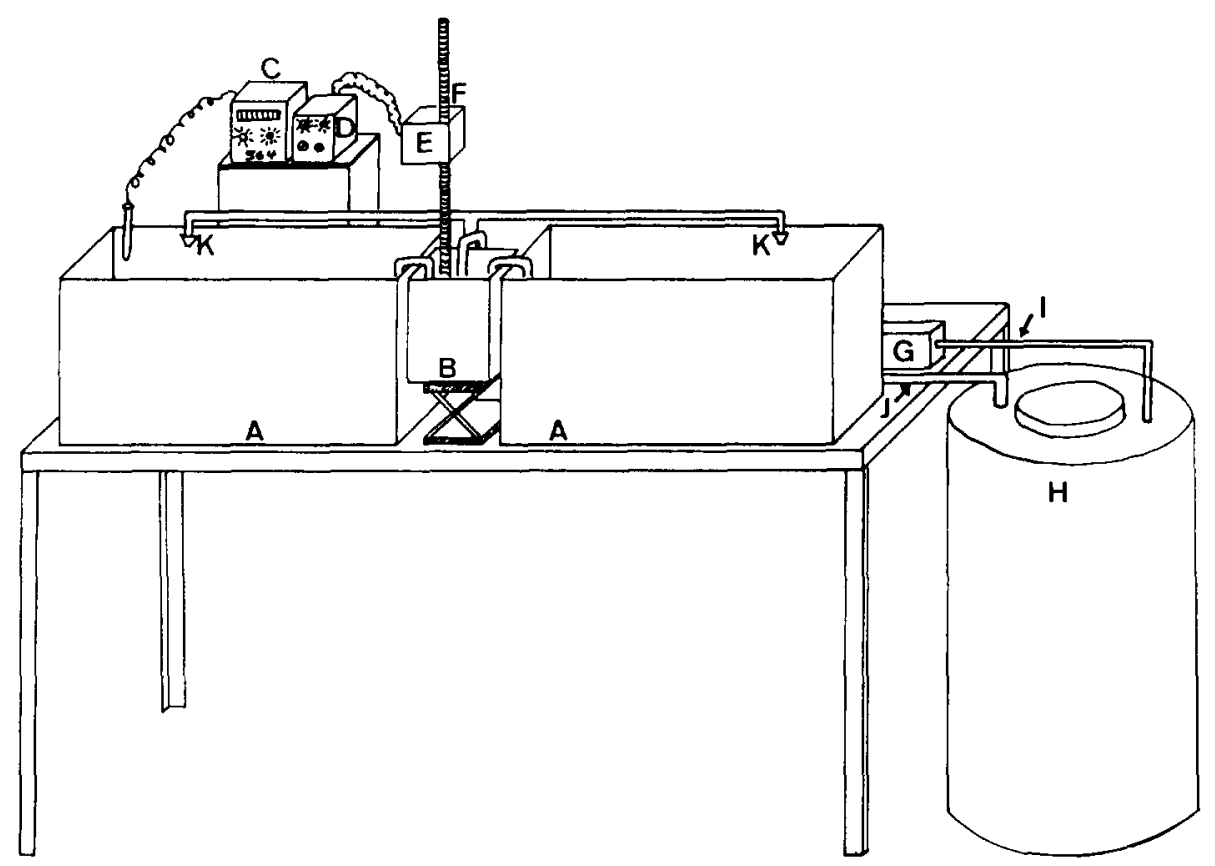

Fig. 1. Schematic diagram of the experimental set-up. A, 110 liter aquaria; $\mathrm{B}$, mixing chamber; $\mathrm{C}$, pHmeter; $D$, titration unit; $E$, solenoid valve; $F$, acid burette; $G$, water pump; $H$, exchangeable medium tank; $\mathrm{I}$, medium outflow from tank; J, medium inflow into tank; K, injector. 
(Table I) was prepared by adding inorganic salts to deionized water as described by the U.S. EPA guidelines (EPA-660/3-75.00). Aluminium was added as anhydrous $\mathrm{AlCl}_{3} .50 \%$ of the test solutions or control water was replaced every $48 \mathrm{~h}$ to maintain the concentration of aluminium and the other electrolytes. $\mathrm{pH}$ was kept constant by an automatic titration unit (Metrohm $564 \mathrm{pH}$-meter) using $1 \mathrm{~N} \mathrm{HCl}$ for titration. $\mathrm{pH}$ was adjusted whenever the value exceeded the nominal value by $0.05 \mathrm{pH}$ units.

\section{Experimental protocol}

Ten one year old rainbow trout (Salmo gairdneri, R.) were put into each of the two experimental units, i.e. ten fish into the exposure unit and ten fish into the control unit, respectively. Six experiments, including the corresponding controls, were carried out (Table II) and lasted 96 hours or until 50\% of the fish in the exposure unit had lost their equilibrium (Manifestation Time, $\mathrm{MT}_{50}$, Mueller, 1980). Upon reaching the $\mathrm{MT}_{50}$ the remaining fish from the exposure unit and all fish from the control unit were removed from the tanks, anaesthetized with $100 \mathrm{mg} \mathrm{MS-222/1} \mathrm{(Sandoz} \mathrm{AG,}$ Basel, Switzerland), blood sampled, and dissected. Hematocrit was determined immediately thereafter and plasma samples were taken for $\mathrm{A} 1, \mathrm{Na}$, and whenever sufficient plasma was available for $\mathrm{Cl}$ determinations. Gill, kidney, and liver samples were taken for histopathology. Samples for water analysis and aluminium fractionation were taken at the beginning, every $24 \mathrm{~h}, 2 \mathrm{~h}$ after the exchange of $50 \%$ of the medium, and at the end. The experiments were carried out in succession and within one year.

TABLE II

pH VALUES AND NOMINAL ALUMINIUM ADDED TO THE EPA SOFTWATER MEDIUM (TABLE I) AND ALUMINIUM FRACTIONS ANALYSED (ARITHMETIC MEAN \pm S.D.) DURING THE COURSE OF THE EXPERIMENTS

\begin{tabular}{|c|c|c|c|c|c|c|c|c|c|}
\hline \multirow{2}{*}{$\begin{array}{l}\text { Exp. } \\
\text { No. }\end{array}$} & \multirow[t]{2}{*}{$\mathrm{pH}$} & \multicolumn{2}{|c|}{ Aluminium added } & \multicolumn{6}{|c|}{ Aluminium analysed } \\
\hline & & $\begin{array}{l}\text { Control } \\
(\mu \mathrm{g} \mathrm{Al} / 1)\end{array}$ & Exposure & $\begin{array}{l}\text { Total Al } \\
(\mu \mathrm{g} \mathrm{Al} / 1)\end{array}$ & $(n)^{\mathrm{a}}$ & $\begin{array}{l}\text { Labile Al } \\
(\mu \mathrm{g} \mathrm{Al} / 1)\end{array}$ & $(n)$ & $\begin{array}{l}\text { Suspended A1 } \\
(\mu \mathrm{g} \mathrm{A} 1 / \mathrm{l})\end{array}$ & $(n)$ \\
\hline 1 & 5.2 & 0 & 100 & $137 \pm 32$ & (5) & $92 \pm 10$ & $(5)$ & $43 \pm 37$ & $(5)$ \\
\hline 2 & 5.2 & 0 & 200 & $203 \pm 12$ & (2) & $175 \pm 21$ & (2) & $14 \pm 11$ & (2) \\
\hline 3 & 5.4 & 0 & 200 & $142 \pm 54$ & (6) & $123 \pm 41$ & (2) & $39 \pm 33$ & (2) \\
\hline 4 & 5.4 & 0 & 400 & $490 \pm 140$ & (3) & $193 \pm 24$ & (3) & $293 \pm 97$ & (3) \\
\hline 5 & 5.6 & 0 & 200 & $173 \pm 58$ & (6) & $63 \pm 46$ & (6) & $102 \pm 42$ & (6) \\
\hline 6 & 5.6 & 0 & 400 & $530 \pm 514$ & (3) & $341 \pm 462$ & (3) & $166 \pm 164$ & $(3)^{b}$ \\
\hline
\end{tabular}

${ }^{a}(n)$, the number of samples analysed. bIn this experiment the first water sample for aluminium fractionation was taken from the mixing chamber before the aluminium was homogeneously dissolved in the total volume of the medium. 


\section{Blood samples}

Blood was taken from the anaesthetized fish by puncturing the heart (Lehmann and Stuerenberg, 1980) with a heparinized hypodermic needle (Li-Heparin, TerumoLuer $\left.18 \mathrm{G} \times 11_{2}{ }_{2}^{\prime \prime}\right)$ and letting the blood run into a $2 \mathrm{ml}$ heparinized polystyrol tube (Milian AG, Geneva, Switzerland).

\section{Hematocrit}

Microhematocrit capillaries (Capilet-C, American Dade, USA) were filled to the mark with wholeblood samples and sealed on both ends with tube sealer. The capillaries were then placed into a hematocrit-fuge (Readacrit, Clay Adams, USA) and centrifuged for $5 \mathrm{~min}$. Hematocrit values were determined by laying the capillaries onto a microhematocrit scale $(0-100 \%$ in $1 \%$ units, Heraeus Co., FRG).

\section{Plasma Na and Cl analysis}

Plasma $\mathrm{Na}$ was analysed on a Corning 435 flamephotometer (Corning Ltd, UK), having a detection limit of $1 \mathrm{mM} \mathrm{Na} / 1$. The flamephotometer was calibrated using Corning $140 \mathrm{mM} \mathrm{Na} / \mathrm{l}$ standard.

All plasma $\mathrm{Cl}$ analyses were done at the Children's Hospital in Zurich using coulometric titration on an Analyzer 929 (Corning Ltd, UK), calibrated with aqueous chloride standards, and a detection range of $10-150 \mathrm{mM} \mathrm{Cl} / 1$.

\section{Histopathology}

Gill (2nd gill arch, left side, direction 'tail-head'), kidney (middle section), and liver samples were taken and put immediately into $4 \%$ buffered $\left(\mathrm{pH} 6.5-6.8, \mathrm{CaCO}_{3}\right)$ formaldehyde solution. These samples were then dehydrated in an increasing series of ethanol i.e. $70 \%, 95 \%$, and $100 \%$, embedded in paraffin, and cut into $5 \mu \mathrm{m}$ thin slices. After gently placing the tissue slices onto a microscope glass-slide, they were deparaffinized for $15 \mathrm{~min}$ in xylene, stained with hematoxylin-eosin, and inspected under the microscope.

\section{Aluminium fractionation}

Aluminium fractionation was carried out on $100 \mathrm{ml}$ samples within $2 \mathrm{~h}$ after taking the samples. The fractionation technique used was basically the same as described by Barnes (1975) and later modified by LaZerte (1984) though no dialysis or cation exchange resin steps were carried out but an extra MIBK extraction step introduced in turn (Fig. 2).

Of the fractions A-G only the fractions A-D were analysed. Fractions E, F, and $G$ were calculated by subtraction, e.g. $A-B=E$. The labile aluminium concentrations are identical with the inorganic monomeric fraction and thus can be calculated (C-D or $\mathrm{G}-\mathrm{F}=$ labile aluminium). All fractions were acidified with $65 \%$ quartz-distilled $\mathrm{HNO}_{3}$ to an approximate $\mathrm{pH}$ of 1 prior to analysis. 


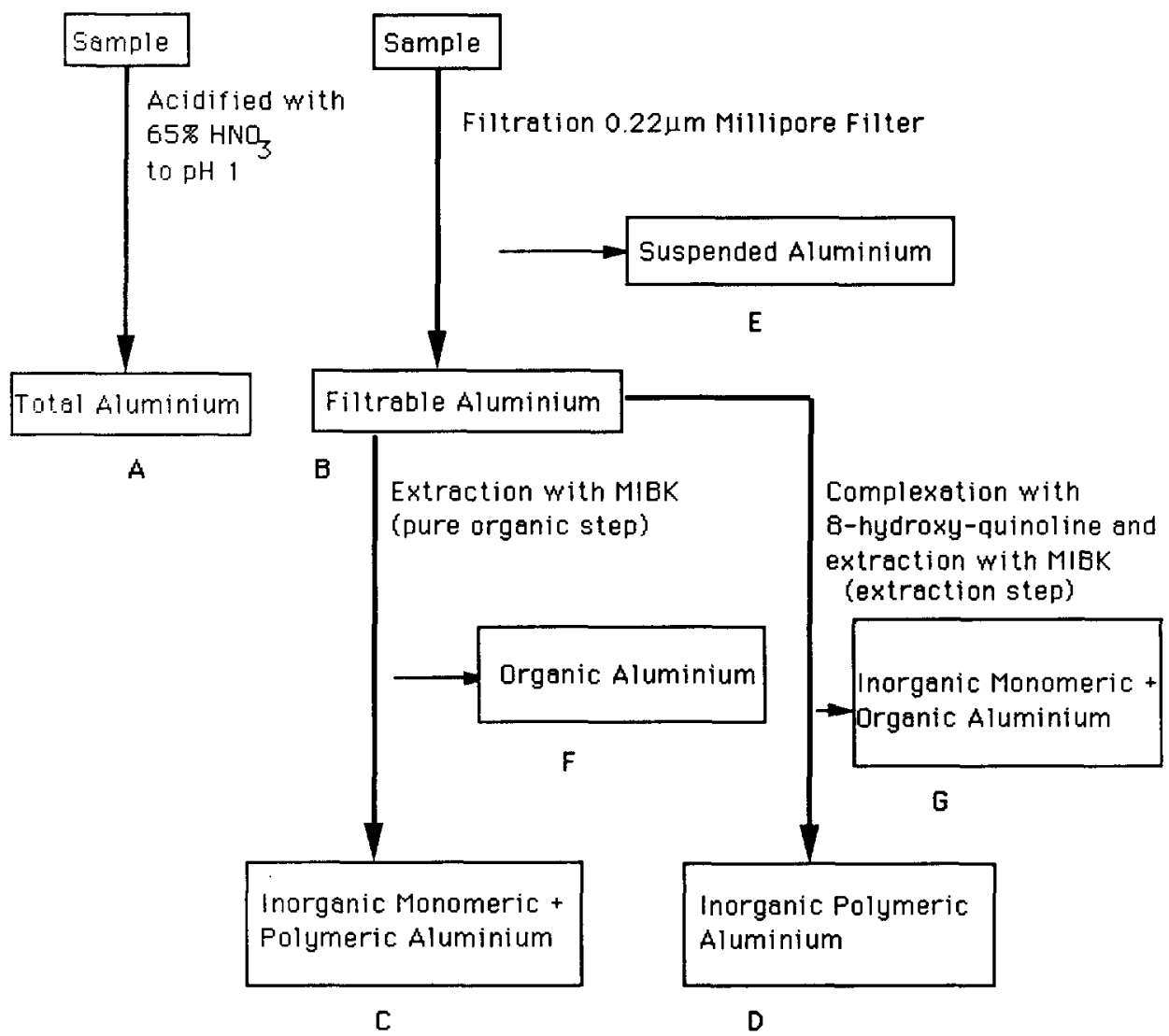

Fig. 2. Aluminium fractionation scheme. Bold letters denote different aluminium fractions.

\section{Aluminium analysis}

The analyses of the plasma samples and the different Al-fractions were done by electrothermal atomic absorption spectrometry (ETAAS) on a Perkin-Elmer model consisting of a HGA 500 graphite furnace, a model 5000 spectrophotometer, and an AS-1 autosampler. All samples were calibrated using the method of standard additions. More detailed information as to this method and the detection limits of ETAAS are given by Rickenbacher (1984) and Kaenzig et al. (1987). Each water sample was injected into the ETAAS four times. The standard deviation of these repetitive analyses was $\pm 5 \mu \mathrm{g} \mathrm{Al} / 1$. For all sample types one temperature program was used (Table III). The usual procedure was to mix $100 \mu \mathrm{l}$ of sample diluent $(0.25 \%$ Triton X-100 in doubly distilled $\mathrm{H}_{2} \mathrm{O}$ ), $50 \mu \mathrm{l}$ of sample, and $50 \mu \mathrm{l}$ of aluminium standard within the ETAAS sample cups. The standards 0,50 , and $100 \mathrm{ppb} \mathrm{Al}$ were made up from a $1000 \mu \mathrm{g} \mathrm{Al} / 1$ solution (Fixanal, Riedel-de-Häen AG, Hannover, FRG) and acidified with quartz distilled $\mathrm{HNO}_{3}$ to $\mathrm{pH}$ 3. The quality of the aluminium analysis 
TABLE III

TEMPERATURE PROGRAM USED FOR AI ANALYSIS BY ETAAS

\begin{tabular}{lccc}
\hline Steps & Temperature $\left({ }^{\circ} \mathrm{C}\right)$ & Ramp $(\mathrm{s})$ & Hold $(\mathrm{s})$ \\
\hline Drying & 110 & 10 & 15 \\
Ashing & 1450 & 10 & 10 \\
Cooling & 20 & 1 & 2 \\
Atomizing & 2200 & 0 & 5 \\
Cleaning & 2500 & 1 & 3 \\
\hline
\end{tabular}

by ETAAS was controlled by participating in a monthly round-robin 'Trace Element Assessment Scheme' (Trace Element Reference Center, Guildford, UK) analyzing aluminium in water, dialysis fluids, and sera.

\section{Statistical analyses}

The values in the tables are arithmetic mean \pm SD. Significant differences between acid-exposed and acid-aluminium exposed fish were identified by the Wilcoxon, Mann-Whitney two-tailed $U$-test and are shown as ${ }^{* *}$ for $P<0.01$ and ${ }^{*}$ for $P<0.05$.

\section{RESULTS}

\section{Aluminium fractionation}

The total aluminium concentrations (labile and suspended) were not stable over the whole length of the experiments (Table II). Total aluminium concentrations declined with increasing time after initial addition and also after the initial concentration level was restored by exchange of $50 \%$ of the medium during the experiments (after $48 \mathrm{~h}$ ). This decline, also registered as a decrease in labile-Al concentration (Fig. 3 ), was most pronounced in the experiments with high aluminium concentrations and moderately low $\mathrm{pH}$, whereas this effect was almost negligible in the experiments with low $\mathrm{pH}$ and relatively low aluminium concentrations. Similar observations were already described by Witters et al. (1987) and Karlsson-Norrgren et al. (1986) who attributed this effect to an enhanced formation and precipitation of polymeric $\mathrm{Al}(\mathrm{OH})_{3}$. The mean total-Al concentration in the waters of all control experiments was $10 \pm 5 \mu \mathrm{g} \mathrm{Al} / 1$.

\section{Mortality and observed symptoms}

No mortality was recorded in any of the exposures without added $\mathrm{Al}$ (controls) with the exception of the experiment at $\mathrm{pH} 5.2$ where one fish was lost due to a severe infestation with the protozoan ectoparasite Costia necatrix. No mucus accumulation or hyperventilatory response could be detected in any of the experiments without added $\mathrm{Al}$. 


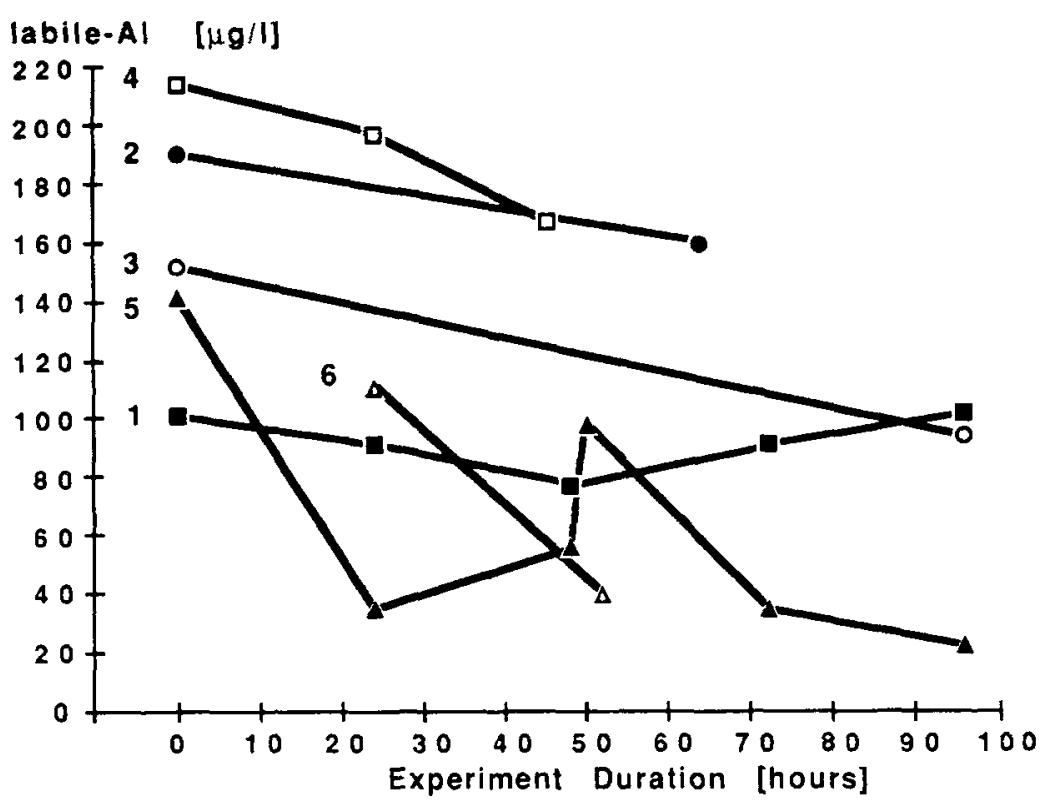

Fig. 3. Labile-Al concentrations in the six experiments. $\bullet, \mathrm{pH} 5.2$ and $200 \mu \mathrm{g} \mathrm{Al} / \mathrm{l} ; \mathrm{O}, \mathrm{pH} 5.4$ and 200 $\mu \mathrm{g} \mathrm{Al} / 1 ; \boldsymbol{\square}, \mathrm{pH} 5.2$ and $100 \mu \mathrm{g} \mathrm{Al} / 1 ; \square, \mathrm{pH} 5.4$ and $400 \mu \mathrm{g} \mathrm{Al} / 1 ; \Delta, \mathrm{pH} 5.6$ and $200 \mu \mathrm{g} \mathrm{Al} / 1 ; \triangle, \mathrm{pH} 5.6$ and $400 \mu \mathrm{g} \mathrm{Al} / 1$.

Coughing, increase of ventilation rate, slight darkening of the body coloration, frequent spasms interspersed with longer periods of immobility, and eventually loss of equilibrium before death could be observed in all of the Al-exposure experiments, although the intensity of the symptoms varied with $\mathrm{pH}$ and Al-concentration. No accumulation of mucus could be detected at $\mathrm{pH}$ 5.2. Slightly enhanced production of mucus was recorded at $\mathrm{pH} 5.4$ and $200 \mu \mathrm{g} \mathrm{Al} / \mathrm{l}$, while moderate and extensive mucification resulted from exposing the fish to $\mathrm{pH} 5.4$ and $400 \mu \mathrm{g} \mathrm{Al} / \mathrm{l}, \mathrm{pH} 5.6$ and 200 $\mu \mathrm{g} \mathrm{Al} / 1$, and $\mathrm{pH} 5.6$ and $400 \mu \mathrm{g} \mathrm{Al} / 1$, respectively. Fish dying at $\mathrm{pH} 5.2$ and $200 \mu \mathrm{g}$ $\mathrm{Al} / 1$ did not exhibit gaping opercula, although this was seen at $\mathrm{pH} 5.4$ and $400 \mu \mathrm{g}$ $\mathrm{Al} / 1, \mathrm{pH} 5.6$ and $200 \mu \mathrm{g} \mathrm{Al} / \mathrm{l}$, or $400 \mu \mathrm{g} \mathrm{Al} / 1.200 \mu \mathrm{g} \mathrm{Al} / 1$ was lethal to $50 \%$ of the exposed fish within $64 \mathrm{~h}$ at $\mathrm{pH} 5.2$, no deaths occurred at pH 5.4, and three fish out of ten died within $96 \mathrm{~h}$ at $\mathrm{pH} 5.6$.

\section{Histopathology}

Compared to fish kept at a pH 7.6 (Dietrich, 1988), the gills of the fish exposed to acid water alone revealed only minor alterations, regardless of the $\mathrm{pH}$ used. These alterations consisted mainly of lifting of the epithelial layer, some cell necrosis, and pyknosis of epithelial, chloride, and mucus cells.

The gills of the fish exposed to aluminium were all damaged. At pH 5.2, the damage increased with increasing aluminium concentration and consisted predominantly 
of lamellar fusions, cell proliferation, and epithelial lifting leading to the loss of gill structure and congestion of the interlamellar space with cell debris and proliferating cells. At pH 5.4 and $200 \mu \mathrm{g} \mathrm{Al} / 1$ the degree of tissue damage was moderate and in addition, enhanced mucification was observed. Almost complete obstruction of the interlamellar space with mucus was recorded at $\mathrm{pH} 5.4$ and 5.6 with $400 \mu \mathrm{g} \mathrm{Al} / \mathrm{l}$. A similar observation was made in the experiment at pH 5.6 with $200 \mu \mathrm{g} \mathrm{Al} / 1$, though the mucification was not as extensive. The gill tissue damage in the latter three experiments was low in comparison to the damage reported for the experiment at $\mathrm{pH} 5.2$ with $200 \mu \mathrm{g} \mathrm{Al} / 1$.

Liver or kidney tissue damage was not induced by exposing fish to aluminium. This observation stands in contrast to reports by Schofield and Trojnar (1980) and Tandjung et al. (1982) who found a correlation between increasing degrees of liver and kidney tissue damage in brook trout exposed to aluminium concentrations $>200 \mu \mathrm{g}$ $\mathrm{Al} / \mathrm{l}$.

\section{Plasma aluminium concentration ( $P A C$ )}

A slight increase of PAC with increasing exposure time can be detected in the experiments without added $\mathrm{Al}$ (Fig. 4): The mean $\mathrm{PAC}$ in the experiments of a shorter duration ( 45.5 to $64 \mathrm{~h}$ ) was $33 \pm 6 \mathrm{ng} \mathrm{Al} / \mathrm{ml}$ whereas the corresponding value in the experiments lasting $96 \mathrm{~h}$ was $50 \pm 12 \mathrm{ng} \mathrm{Al} / \mathrm{l}$. The stress of being exposed to low $\mathrm{pH}$ could have caused a redistribution of the body $\mathrm{Al}$ which would explain the higher PAC levels and the considerable variation of the PAC levels in the control experiments lasting $96 \mathrm{~h}$. The mean PAC levels of fish exposed to acid water alone are not different from the mean PAC levels measured in rainbow trout kept in Lake Zurich water at a pH 7.6 for four weeks (Dietrich, 1988). The PAC values in the Al experiments were only slightly higher than in the corresponding experiments without added $\mathrm{Al}$ (Table IV and Fig. 4).

\section{Plasma electrolytes and hematocrit}

$\mathrm{Na}$ The plasma Na concentrations in the acid-experiments varied in the range between $142-167 \mathrm{mEq} / \mathrm{l}$ whereas the lowest values can be found in the $\mathrm{pH} 5.2$ experiments (Table IV). Compared to published values (Neville, 1985; Wheatley et al., 1984; and McDonald et al., 1980) they still are in the normal range. With the exception of the experiment at $\mathrm{pH} 5.6$ and $200 \mu \mathrm{g} \mathrm{Al} / 1$, all Na values of the acid-Al experiments are lower than the $\mathrm{Na}$ values found in their corresponding experiments without added aluminium. The most pronounced effects were induced at $\mathrm{pH} 5.2$ and 5.4 and $200 \mu \mathrm{g} \mathrm{Al} / 1$.

$\mathrm{Cl}$ Plasma chloride concentration measurements revealed that the mean plasma chloride concentrations are generally equal to or slightly lower than values found in literature (Neville, 1985, Wheatley et al., 1984, Thomas and Hughes, 1982, and McDonald et al., 1980). High aluminium concentrations ( $400 \mu \mathrm{g} \mathrm{Al} / 1)$ seemed to induce a loss of plasma chloride. On the whole, the effects of $\mathrm{pH}$ and $\mathrm{Al}$ on plasma chloride concentration were almost negligible (Table IV). 

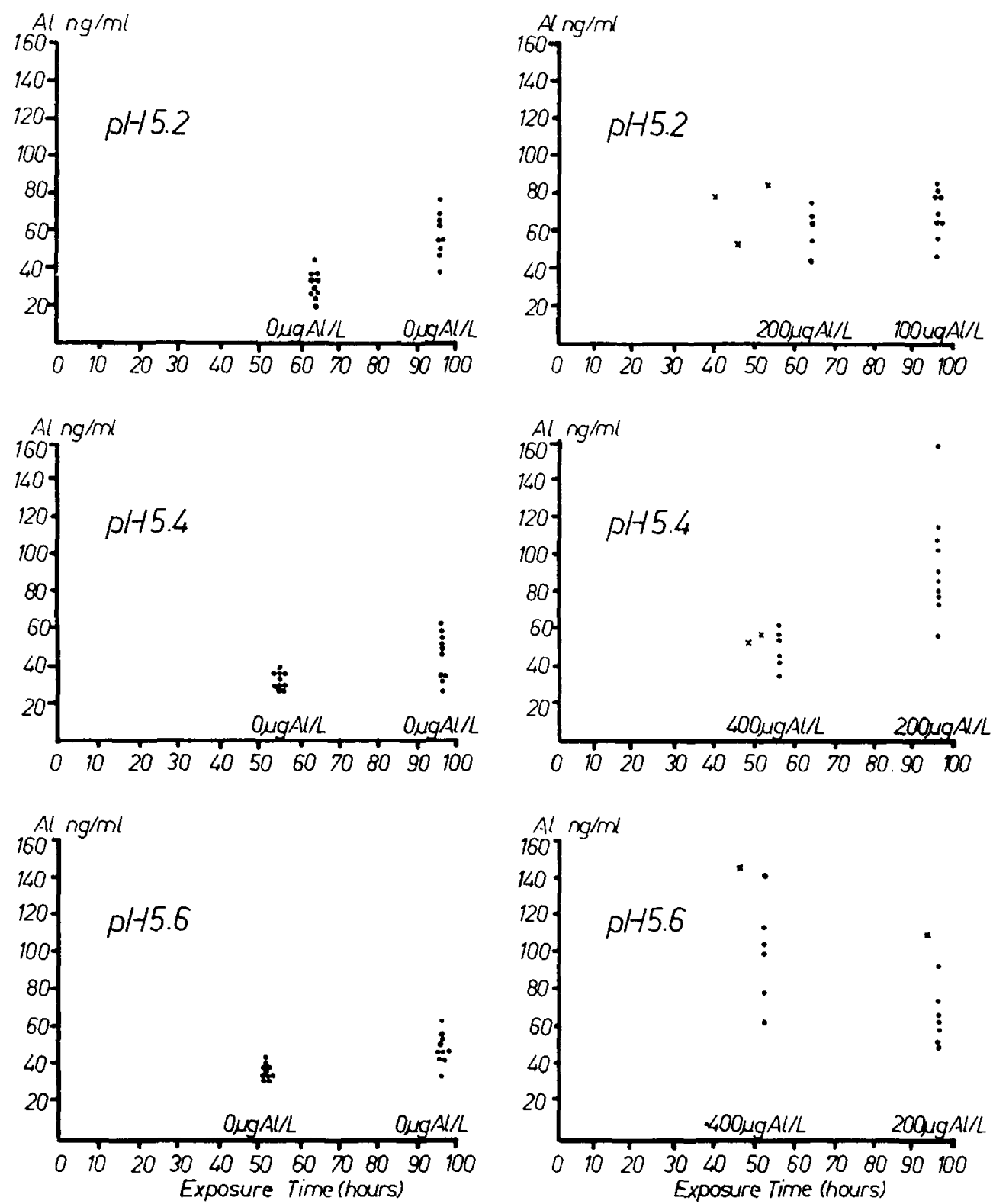

Fig. 4. Plasma aluminium concentrations (PAC). + denote fish sampled just before death and - fish sampled after termination of the experiment. The figure does not show fish that had died without being sampled. The nominal aluminium concentration added is indicated below the symbols. 
TABLE IV

MEANS AND STANDARD DEVIATIONS (IN BRACKETS) OF BLOOD PARAMETERS AND MANIFESTATION TIMES ( $\left.\mathrm{MT}_{50}\right)$.

\begin{tabular}{|c|c|c|c|c|c|c|}
\hline $\mathrm{pH}$ & $\begin{array}{l}\text { Water aluminium } \\
\text { nominal }(\mu \mathrm{g} / 1)\end{array}$ & $\mathrm{Al}(\mathrm{ng} / \mathrm{l})$ & $\begin{array}{l}\text { Plasma } \\
\mathrm{Na}(\mathrm{mEq} / \mathrm{l})\end{array}$ & $\mathrm{Cl}(\mathrm{mEq} / \mathrm{l})$ & $\begin{array}{l}\text { Hematocrit } \\
(\%)\end{array}$ & $\begin{array}{l}\mathrm{MT}_{50} \\
\text { (h) }\end{array}$ \\
\hline & 0 & $56 \quad(12)$ & 142 ( 2) & $124 \quad(5)$ & $38 \quad(5)$ & - \\
\hline \multirow[t]{2}{*}{5.2} & 100 & $67 \quad$ (13) & $132 * *(5)$ & 124 & $45^{*}(5)$ & - \\
\hline & 0 & $31 \quad(8)$ & $144 \quad(10)$ & n.m. & $39 \quad(7)$ & - \\
\hline \multirow[t]{2}{*}{5.2} & 200 & $63^{* *}(14)$ & $113^{* *}(8)$ & n.m. & $54^{* * *}(3)$ & 64 \\
\hline & 0 & $45 \quad$ (13) & 167 & n.m. & $38 \quad(7)$ & - \\
\hline \multirow[t]{2}{*}{5.4} & 200 & $93 * *(29)$ & $117^{* *}(15)$ & n.m. & 41 (9) & - \\
\hline & 0 & 32 (4) & 152 (4) & $122 \quad(6)$ & $50 \quad(8)$ & \\
\hline \multirow[t]{2}{*}{5.4} & 400 & $50^{* *}(9)$ & $139 * *(3)$ & $108^{* *}(9)$ & $61 *(9)$ & 45.5 \\
\hline & 0 & $47 \quad(8)$ & 149 (3) & 119 & $51 \quad(5)$ & - \\
\hline \multirow[t]{2}{*}{5.6} & 200 & $68^{* *}(2 \mathrm{I})$ & $145 \quad(5)$ & $118 \quad(8)$ & $56 \quad(7)$ & - \\
\hline & 0 & $35 \quad(4)$ & 150 (4) & $128 \quad(4)$ & $46 \quad(6)$ & - \\
\hline 5.6 & 400 & $105^{* *}(30)$ & $142^{* *}(4)$ & $117^{* *}(9)$ & $61^{* *}(3)$ & 52 \\
\hline
\end{tabular}

Asterisks denote values significantly different from the corresponding control value $\left({ }^{* *} P<0.0 \mathrm{I}\right.$ and ${ }^{*} P<0.05 ;$ n.m. $=$ not measured $)$.

Hematocrit The mean hematocrit values of the acid only exposed fish were all in the range considered normal (Lehman et al., 1976). In the experiments with added Al the hematocrits were increased (Table IV). The mean hematocrit values were always considerably elevated in groups where deaths occurred.

\section{DISCUSSION}

\section{Mortality and symptoms}

The main symptoms at pH 5.4 and 5.6 combined with 200 or $400 \mu \mathrm{g} \mathrm{Al} / 1$ were high coughing rates and extensive mucification of the gills. Similar observations were reported earlier by Neville (1985), who exposed rainbow trout (Salmo gairdneri R.) to $75 \mu \mathrm{g} \mathrm{Al} / 1$ and $\mathrm{pH} 5.5$, using $\mathrm{Al}_{2}\left(\mathrm{SO}_{4}\right)_{3}$ as an aluminium source. In view of the fact that mucification of the gills occurred irrespective of the aluminium compound used for experimentation, the suggestion of Rosseland and Skogheim (1984) and Rosseland et al. (1988), that the use of aluminium as sulphate salt may be the cause for the reported mucifications, can be disproved. Clogging of the gills with mucus will raise the diffusional resistance to $\mathrm{O}_{2}$ and reduce the water flow through the sec- 
ondary lamellae (Ultsch and Gros, 1979) leading to asphyxia. As no substantial sodium loss was registered, it seems that the gills' function in regulating electrolytes was at least not heavily impaired.

Mucification is always, with the exception of Neville's observation (1985), reported in connection with the use of high ( $>200 \mu \mathrm{g} \mathrm{Al} / \mathrm{l}$ ) aluminium concentrations (Muniz and Leivestad, 1980b, Rosseland and Skogheim, 1984). Especially in the $\mathrm{pH}$ range 5.4 to 5.8, where aluminium solubility is lowest (Burrows, 1977), aluminium will tend to polymerize and precipitate. Precipitating polymeric-Al may accumulate on the gill surface as a result of the negatively charged mucus (McDonald, 1983). As the gill serves as an excretion organ for ammonia, the slight increase in $\mathrm{pH}$ directly on the gill surface may further enhance the precipitation and accumulation of aluminium (Wood and McDonald, 1987). The reported mucifications in our experiments coincided with polymeric-Al concentrations that were higher than $100 \mu \mathrm{g} \mathrm{Al} / 1$ in the medium (Table II). The precipitating polymeric-Al probably exerts a moderate cytotoxic effect on the gills leading to mucus secretion. Precipitation of polymeric-Al onto the gills thus represents a mechanism of aluminium toxicity inherent to conditions with high aluminium concentrations and moderately low $\mathrm{pH}$.

Precipitation of aluminium in experimental waters and accumulation of aluminium on the gills is not only reported for recirculating test systems (our experiments, Karlsson-Norrgren et al., 1986), but also for flowthrough systems (Muniz and Leivestad, 1980b, Schofield and Trojnar, 1980, Neville, 1985), and for field experiments (Grahn, 1980, Dickson, 1983). It may thus be concluded further that the observed mucifications do not represent a laboratory artefact as has been suspected by Rosseland et al. (1988). The fact that Skogheim et al. (1984) did not detect mucification in their studies with atlantic salmon (Salmo salar) in the $\mathrm{pH}$ range 4.7 to 6.0 with aluminium concentrations ranging between 47 and $394 \mu \mathrm{g} \mathrm{Al} / 1$ remains unexplained. In the low $\mathrm{pH} /$ low aluminium experiments a loss of sodium and the lack of mucification were the most outstanding observations made. As the electrolyte loss was quite comparable at pH 5.2 and pH 5.4 with $200 \mu \mathrm{g} \mathrm{Al} / 1$, another factor, not seen at the other conditions, had to be responsible for the mortality at pH 5.2 and $200 \mu \mathrm{g} \mathrm{Al} / \mathrm{l}$ : histopathological preparations of the gills of the fish exposed in experiments 1,2 and 3 (Table II) revealed that heavy damage resulted from exposure to $\mathrm{pH} 5.2$ and $200 \mu \mathrm{g} \mathrm{Al} / 1$, whereas the gills of the fish exposed to $100 \mu \mathrm{g} \mathrm{Al} / 1$ at pH 5.2 and to $200 \mu \mathrm{g} \mathrm{Al} / 1$ at pH 5.4 were only moderately damaged. The gill damage consisted of fusions of the secondary lamellae, hyperplasia, and desquamation of the gill epithelia, leading to an obstruction of the interlamellar space and thus to a reduction of water flow and gas exchange within the gills. The obvious question arises why a concentration of $200 \mu \mathrm{g} \mathrm{Al} / 1$ is markedly more cytotoxic at $\mathrm{pH} 5.2$ than at $\mathrm{pH} 5.4$. Our Al-fractionation shows that a greater amount of aluminium exists in the labile (inorganic monomeric) form at $\mathrm{pH} 5.2$ than at $\mathrm{pH} 5.4$ (Fig. 3), thus suggesting that the labile-Al exerts a marked cytotoxic effect on the gills. It must be added though that our method of Al-fractionation is far from being perfect and may overestimate the labile fraction, 
due to the fact that some polymeric-Al might pass the $0.22 \mu \mathrm{m}$ filter.

These findings corroborate the observations of Jagoe et al. (1987) who reported similar gill damage in Salmo salar exposed to pH's between 4.5 and 5.5 and aluminium concentrations greater than $75 \mu \mathrm{g} \mathrm{Al} / 1$, though these damages were not explicitly attributed to monomeric-Al species. Rosseland and Skogheim (1984), on the other hand, found no gill damage in brown trout (Salmo trutta, L.) exposed to pH 5.0 and $130-462 \mu \mathrm{g} \mathrm{Al} / 1$, dying of electrolyte loss. This discrepancy may be explained by strain differences in the susceptibility towards the damaging effects of $\mathrm{Al}$ and low $\mathrm{pH}$, shown previously to be of importance in the effects of $\mathrm{Al}$ and low $\mathrm{pH}$ on electrolyte loss (Rosseland and Skogheim, 1987).

\section{Plasma aluminium}

Though various previous efforts to measure aluminium in blood of fish exposed to aluminium at low pH by the pyrocatechol method (Dougan and Wilson, 1974) were undertaken previously (Wood and McDonald, 1987, Neville, 1985, and Dalziel et al., 1986 and 1987), no aluminium was detected. Whether the lack of aluminium detection was due to the detection limits of the pyrocatechol method or to the inadequacy of the method for aluminium detection in biological materials cannot be determined, especially as no detailed information about the detection limits, procedures of analysis, and results were given. Our plasma analyses, on the other hand, revealed higher PAC levels in fish exposed to aluminium than in fish of the experiments without added $\mathrm{Al}$ (Table IV). It is surprising that the plasma aluminium values of the control fish are approximately a factor ten higher than the normal values found in man. This might be due to the $\mathrm{Al}$ content in the water and in the trout feed, which was high (135 $\pm 24 \mu \mathrm{g} \mathrm{Al} / \mathrm{g}$ wet weight, Dietrich, 1988) compared to the human diet (daily human intake of $4 \mathrm{mg} \mathrm{Al}$, Knutti and Zimmerli, 1985). It seems however that the uptake of aluminium from the water is small since the increase of plasma concentration in the groups with $200-400 \mu \mathrm{g} \mathrm{Al} / 1$ was only slight, going from $31-56 \mathrm{ng} \mathrm{Al} / \mathrm{ml}$ of the controls to $50-105 \mathrm{ng} \mathrm{Al} / \mathrm{ml}$ of the exposed fish (Table IV). It is not likely that this slight increase of aluminium in the plasma of aluminium exposed fish would have any pronounced effects on either mortality, hematocrit, or electrolyte loss; indeed no correlation was found between plasma Al and these parameters. Our findings thus suggest that plasma aluminium is not a factor in the acute toxicity of aluminium to fish.

\section{Hematocrit}

Leivestad (1982) and Rosseland and Skogheim (1984) found that an increase in hematocrit was always associated with an extensive electrolyte loss in fish exposed to aluminium at low $\mathrm{pH}$. We could not confirm these findings, as we recorded high hematocrit values in our experiments whether the fish exposed faced an increased electrolyte loss or not. On the other hand, high hematocrit values were always associated with dying fish. Lehmann and Stuerenberg (1981) found that any kind of stress 
can induce an increase in hematocrit in fish. Thus our opinion is that the high hematocrits reported in many studies may reflect an unspecific response of the fish to an extremely stressing situation, closely associated with a preterminal condition, rather than an indication of extreme electrolyte loss.

In conclusion, at $\mathrm{pH}$ values lower than 5.4 and $\mathrm{Al}$ concentrations higher than 100-200 $\mu \mathrm{g} \mathrm{Al} / 1$, two major mechanisms may lead to the death of trout: one being electrolyte loss possibly being induced by an interaction of aluminium with enzymes and epithelial tight junctions; and the second being the cytotoxicity of labile-Al to the gill epithelia leading to necrosis, proliferations, and fusions of the secondary lamellae, finally resulting in the impairment of gas exchange.

At higher $\mathrm{pH}$ levels these two effects decrease in intensity whereas mucification increases, an effect which seems to be induced mainly by polymeric Al. The predominance of one of the three mechanisms may depend on the susceptibility of the fish strain, the $\mathrm{pH}$, and the aluminium concentration.

\section{ACKNOWLEDGEMENTS}

We are grateful to Dr. Blau and his staff at the Children's Hospital of Zurich for the chloride analyses. We are also indebted to A.M. Forss for her valuable assistance during the experiments. This study was financed by the Swiss National Research Foundation, grant No. 3.137-0.85.

\section{REFERENCES}

Baker, J.P., 1982. Effects on fish of metals associated with acidification. In: Acid Rain/Fisheries: Proceedings of Int. Symp. on Acidic Precip. and Fish. Impacts on Northeastern North America, editored by Haines and Johnson, Cornell University Press, Ithaca, New York, pp. 165-175.

Barnes, R.B., 1975. The determination of specific forms of aluminium in natural waters. Chem. Geol. 15, 177-191.

Burrows, W.D., 1977. Aquatic aluminium; chemistry, toxicology, and environmental prevalence. CRC Crit. Rev. Environm. Control 167-216.

Dalziel, T.R.K., R. Morris and D.J.A. Brown, 1986. The effects of low pH, low calcium concentrations and elevated aluminium concentrations on sodium fluxes in brown trout, Salmo trutta, L. Water, Air, Soil Pollut. 30, $569-577$.

Dalziel, T.R.K., R. Morris and D.J.A. Brown, 1987. Sodium uptake inhibition in brown trout, Salmo trutta exposed to elevated aluminium concentrations at low pH. Ann. Soc. R. Zool. Belg. 117 (suppl. 1), $421-434$.

Dickson, W., 1983. Limiting toxicity of aluminium to fish. Vatten $39,400-404$.

Dietrich, D.R., 1988. Aluminium toxicity to salmonids at low pH. Ph.D. thesis, Swiss Federal Institute of Technology, Institute of Toxicology, Zurich, Switzerland, No. 8715, 210 pp.

Dougan, W.K. and A.L. Wilson, 1974. The absorptiometric determination of aluminium in water. A comparison of some chromogenic reagents and the development of an improved method. Analyst 99 , 413430.

Fivelstad, S. and H. Leivestad, 1984. Aluminium toxicity to atlantic salmon (Salmo salar, L.) and brown trout (Salmo trutta, L.): Mortality and physiological response. Institute of Freshwater Research, Drottningholm Report 61, 69-77. 
Grahn, O., 1980. Fishkills in two moderately acid lakes due to high aluminium concentration. Proc. Int. conf. ecol. impact acid precip. Norway, SNSF-project, 310-313.

Hutchinson, N., K.E. Holtze, J.R. Munro and T.W. Pawson, 1987. Lethal responses of salmonid early life stages to $\mathrm{H}^{+}$and $\mathrm{Al}$ in dilute waters. Ann. Soc. R. Zool. Belg. 117 (suppl. 1), 201-217.

Jagoe, C., T.A. Haines and D.R. Buckler, 1987. Abnormal gill development in atlantic salmon (Salmo salar) fry exposed to aluminium at low pH. Ann. Soc. R. Zool. Belg. 117 (suppl. 1), 375-386.

Kaenzig, A., R. Knutti, Ch. Schlatter, U. Vogelsang and K. Zaruba, 1987. Aluminium transfer during dialysis. In: Trace element-analytical chemistry in medicine and biology, edited by $P$. Braetter and P. Schramel, Walter de Gruyter \& Co., New York, 4, 463-471.

Karlsson-Norrgren, L., I. Björklund, O. Ljungberg and P. Runn, 1986. Acid water and aluminium exposure: experimentally induced gill lesions in brown trout, Salmo trutta L. J. Fish Dis. 9, 11-25.

Kjartansson, H., 1984. Na-K-ATP'ase and residual Mg-ATP'ase activity of the gill, pseudobranch, and kidney tissues from salmonids before and after exposure to aqueous aluminium at low $\mathrm{pH}$. $\mathrm{PhD}$ thesis, University of Bergen, Norway, $92 \mathrm{pp}$.

Knutti, R. and B. Zimmerli, 1985. Untersuchung von Tagesrationen aus schweizerischen Verpflegungsbetrieben. Mitt. Gebiete Lebensm. Hyg. 76, 206232.

Lacroix, G. and D. Townsend, 1987. Responses of juvenile atlantic salmon to episodic increases in the acidity of some rivers of Nova Scotia, Canada. Ann. Soc. R. Zool. Belg. 117 (suppl. 1), 297-307.

LaZerte, B.D., 1984. Forms of aqueous aluminium in acidified catchments of Central Ontario: a methodological analysis. Can. J. Fish. Aquat. Sci. 41, 766-776.

Lehmann, J. and F-J. Stuerenberg, 1980. Techniken zur Blutentnahme bei Suesswassernutzfischen. Fisch Umwelt 8,77-88.

Lehmann, J. and F-J. Stuerenberg, 1981. Die Auswertbarkeit von Blutparametern und Methoden zu ihrer Bestimmung in der Fischtoxikologie. Fisch Umwelt 9, 25-39.

Lehmann, J., F-J. Stuerenberg and F. Hesse, 1976. Haematologisch-serologische Substratuntersuchungen an der Regenbogenforelle (Salmo gairdneri, R.). Gewaesser Abwaesser III, 7-32.

Leivestad, H., 1982. Physiological effects of acid stress on fish. In: Acid rain/fisheries: Proceedings of Int. Symp. on Acidic Precip. and Fish. Impacts on Northeastern North America, editors Haines and Johnson, Cornell University Press, Ithaca, New York, pp. 157-164.

Leivestad, H., I.P. Muniz and B.O. Rosseland, 1980. Acid stress in trout from a dilute mountain stream. Proc. Intl. conf. ecol. impact acid precip., Norway, SNSF-project, 318-319.

Leivestad, H., E. Jensen, H., Kjartansson and L. Xingfu, 1987. Aqueous speciation of aluminium and toxic effects on atlantic salmon. Ann. Soc. R. Zool. Belg. 117 (suppl. 1), 387-398.

McDonald, D.G., 1983. The effects of $\mathrm{H}^{+}$upon the gills of freshwater fish. Can. J. Zool. 61, 691-703.

McDonald, D.G., H. Hoebe and C.M. Wood, 1980. The influence of calcium on the physiological responses of rainbouw trout, Salmo gairdneri, to low environmental pH. J. Exp. Biol. 88, 109-131.

Mueller, R., 1980. Fish toxicity and surface tension of non-ionic surfactants: investigations of antifoam agents. J. Fish Biol. 16, 585-589.

Muniz, I.P. and H. Leivestad, 1980. a. Acidification - effects on freshwater fish. Proc. Int. conf. ecol. impact acid precip., Norway, SNSF-project 84-92. b. Toxic effects of aluminium on the brown trout, Salmo trutta L. Proc. Int. Conf. Ecol. impact acid precip., Norway, SNSF-project, 320-321.

Neville, C.M., 1985. Physiological response of juvenile rainbow trout, Salmo gairdneri, to acid and aluminium - prediction of field responses from laboratory data. Can. J. Fish. Aquat. Sci. 42, 2004-2019.

Rickenbacher, U.J., 1984. Gastrointestinale Absorption und toxische Auswirkungen von Aluminiumverbindungen bei Versuchstieren und exponierten Personen. Ph.D. thesis, Federal Institute of Technology, Institute of Toxicology, Zurich, Switzerland, No. 7480,108 pp.

Rosseland, B.O., 1980. Physiological response to acid water in fish. 2. Effects of acid water on metabolism and gill ventilation in brown trout, Salmo trutta L., and brook trout Salvelinus fontinalis M. Proc., Int. Conf. Ecol. impact acid precip., Norway, SNSF-project, 348-349. 
Rosseland, B.O. and O.K. Skogheim, 1984. A comparative study on salmonid fish species in acid aluminium rich water. II. Physiological stress and mortality of one- and two-year-old fish. Institute of Freshwater Research, Drottningholm Report 61, 186-194.

Rosseland, B.O. and O.K. Skogheim, 1987. Differences in sensitivity to acidic softwater among strains of brown trout (Salmo trutta). Ann. Soc. R. Zool. Belg. 117 (suppl. 1), 255-264.

Rosseland, B.O., T.D. Eldhuset and M. Staurnes, 1989. Environmental effects of aluminium. In: Proc. of the workshop on 'Aluminium and Health'. 2 May, Oslo, Norway, in press.

Schofield, C.L. and J.R. Trojnar, 1980. Aluminium toxicity to brook trout (Salvelinus fontinalis) in acidified water. In: Polluted rain, edited by Toribara, Miller, and Morrow, Plenum Press, New York, 341-366.

Skogheim, O.K., B.O. Rosseland and I.H. Sevaldrud, 1984. Deaths of spawners of atlantic salmon (Salmo salar, L.) in River Ogna, SW Norway, caused by acidified aluminium rich water. Institute of Freshwater Research, Drottningholm Report 61, 195-202.

Staurnes, M., T. Sigholt and O.T. Reite, 1984. Reduced carbonic anhydrase and Na-K-ATPase activity in gills of salmonids exposed to aluminium-containing acid water. Experientia 40, 226-227.

Tandjung, S.D., D.V. Rottiers and R.L. Hermann, 1982. Histopathological studies on the effects of acid stress to brook trout Salvelinus fontinalis (Mitchell) in the presence of sublethal concentrations of aluminium. In: Acid rain/Fisheries: Proceedings of Int. Symp. on Acidic Precip. and Fish. Impacts on Northeastern North America, edited by Haines and Johnson, Cornell University Press, Ithaca, New York, pp. 357.

Thomas, S. and G.M. Hughes, 1982. A study of the effects of hypoxia on acid-base status of rainbow trout blood using an extracorporeal blood circulation. Resp. Physiol. 49, 371-382.

Ultsch, G.R. and G. Gros, 1979. Mucus as a diffusion barrier to oxygen: possible role $\mathrm{O}_{2}$ uptake at low pH in carp (Cyprinus carpio, L.) gills. Comp. Biochem. Physiol. 62A, 685-689.

U.S. Environmental Protection Agency, 1975. Method for acute toxicity tests with fish, macroinvertebrates, and amphibians. Guidelines EPA-660/3-75.00.

Water Analysis, 1983. Swiss Federal Guidelines For Water Analysis. 10.83400 A2327/2. Swiss Federal Department of the Interior.

Wheatley, M.G., H. Hoebe and C.M. Wood, 1984. The mechanism of acid-base and ionoregulation in the freshwater rainbow trout during environmental hyperoxia and subsequent normoxia: The role of the kidney. Respir. Physiol. 55, 155-173.

Witters, H.E., J.H.D. Vangenechten, S. Van Puymbroek and O.L.J. Vanderborght, 1987. Ionoregulatory and haematological responses of rainbow trout Salmo gairdneri Richardson to chronic acid and aluminium stress. Ann. Soc. R. Zool. Belg. 117 (suppl. 1), 411-420.

Wood, C.M. and D.G. McDonald, 1987. The physiology of acid/aluminium stress in trout. Ann. Soc. R. Zool. Belg. 117 (suppl. 1), 399-410. 